\title{
PENGEMBANGAN LEMBAR KERJA SISWA MODEL KOOPERATIF TIPE NUMBERED HEADS TOGETHER UNTUK MENINGKATKAN HASIL BELAJAR
}

\author{
Wiwin Purwanti1 (D), Dian Mayasari2*iD), Anis Munfarikhatin ${ }^{3}$ \\ 1Jurusan Pendidikan Matematika Universitas Musamus \\ 2,3Universitas Musamus Merauke, Papua, Indonesia \\ ${ }^{1}$ wiwinpurwanti1234@gmail.com, ${ }^{2 *}$ mayasari fkip@unmus.ac.id, \\ ${ }^{3}$ munfarikhatin fkip@unmus.ac.id
}

Received: February 11,2021 Revised: April 11,2021 $\quad$ Accepted: April 24, 2021

\begin{abstract}
:
The aims of this study were to develop teaching materials of Mathematic Student Worksheets in class VIII SMP using cooperative learning model type Numbered Heads Together (NHT).The type of this research were development with the ADDIE model which were carried out until the implementations and stages due to the COVID-19 pandemic. The Research subject was at SMP Negeri 8 Merauke, in the class VIII by trial sample 6 students with comparison materials. The data collections were carried out through observations, interviews, tests and questionnaires. The results of developing student worksheets are categorized as valid with a percentage value of $95 \%$. The students responses of questionnaire were included in the practical category with an.amount of $81.7 \%$. The teacher response questionnaire included practical criteria with a percentage of $68.75 \%$. The results of learning observations for the first meeting obtained a percentage score of $87 \%$, the second meeting was $80 \%$ so that it met the practical criteria. The results of the $\mathrm{N}$-gain test show that student worksheets using the NHT model can improve students achievement.
\end{abstract}

Keywords: Development, Cooperative Learning, Number Has Together (NHT), Student Worksheet

How to Cite: Purwanti, W., Mayasari, D., Munfarikhatin, A. (2021). Pengembangan Lembar Kerja Siswa Model Kooperatif Tipe Numbered Heads Together untuk Meningkatkan Hasil Belajar. Alifmatika: Jurnal Pendidikan dan Pembelajaran Matematika, 3(1), 70-79 https://doi.org/10.35316/alifmatika.2021.v3i1.70-79

\section{PENDAHULUAN}

Pendidikan merupakan suatu proses terjadinya belajar untuk meningkatkan mutu sumber daya manusia yang berkualitas (Panjaitan, Palenewen, \& Maasawet, 2017). Pendidikan yang berkualitas dapat ditingkatkan dengan perhatian dari pemerintah, masyarakat, guru dan orangtua (Astuti \& Sari, 2017). Kenyataannya saat ini di dalam kelas masih didominasi oleh siswa dan menjadikan merak tergantung pada guru. Kondisi tersebut dapat membuat kreatifitas siswa, penalaran, serta daya pikir yang rendah, mengakibatkan prestasi belajarnya tidak meningkat.

Content from this work may be used under the terms of the Creative Commons AttributionShareAlike 4.0 International License that allows others to share the work with an acknowledgment of the work's authorship and initial publication in this journal. 
Pada proses pembelajaran, khususnya matematika siswa diharuskan berlatih memecahkan masalah, sehingga diharapkan prestasi belajar menjadi meningkat. Prestasi belajar merupakan penguasaan yang dimiliki seseorang yang diketahui setelah melakukan pembelajaran (Taufik et al., 2019). Proses belajar dan mengajar berhasil dengan baik, diperlukan adanya model pembelajaran yang tepat dan mengaitkan siswa secara langsung. Salah satu solusi dari masalah tersebut ialah dengan menerapkan model pembelajaran kooperatif. Kemandirian belajar merupaka cara yang baik untuk siswa lebih siap dalam belajar serta dapat meningkatkan kepercayaan diri, kreatif, dan inovatif (Anwar, Ari, Sri, Widodo, \& Pendahuluan, 2018). Hal itu dapat terlaksana dengan baik, salah satunya dengan menerapkan pembelajaran kooperatif. Pembelajaran kooperatif adalah siswa belajar dan bertindak dengan regu kecil secara kalaboratif yang dibentuk bersifat heterogen (Pagiling, Palobo, Munfarikhatin, Mayasari, \& Taufik, 2019).

Numbered head Together (NHT) merupakan bagian dari model kooperatif dapat mengajak kerjasama aktif dalam memahami materi pelajaran untuk menggapai hasil yang terbaik (Anwar et al., 2018; Ellan, Hobri, \& Nurcholif, 2013). NHT dalam penerapannya memiliki tahapan (Fitriani \& Aksa, 2014; Panjaitan et al., 2017) yang pertama membagi kelompok dan diberi nomor untuk masing-masing anggota, pemberian tugas diskusi dan tiap kelompok mengerjakan, diskusi untuk memperoleh jawaban benar dan pastikan semua anggota paham atau dapat mengerjakan, pemanggilan nomor secara acak untuk menyampaikan hasil diskusi kelompok, sanggahan dari anggota lain, dilanjutkan pemanggilan nomor yang lain dan kesimpulan.

Kelemahan dari NHT pada model kooperatif ialah anggota kelompok tidak memiliki kesempatan terpanggil semua oleh guru, pengondisian kelas kurang, dan butuh waktu lama untuk mengerti materi karena ada diskusi kelompok dan kelas (Natsir, Munfarikhatin, \& Taufik, 2020; Fitriani \& Aksa, 2014). NHT yang merupakan bagian dari cooperatif learning memiliki kelebiahan diantaranya siswa lebih aktif dalam menjawab pertanyaan, mengasah keberanian siswa dalam mengemukakan pendapat dan bicara di depan kelas, motivasi siswa dalam belajar, dan melatih siswa untuk saling membantu dan menghargai pendapat teman dalam kelompok (Taufik et al., 2019; Fitriani \& Aksa, 2014). Peneliti telah melakukan observasi menyimpulkan bahwa prestasi belajar matematika siswa kelas VII SMP Negeri 8 Merauke tergolong rendah. Suasana kelas saat berlangsungnya kegiatan belajar mengajar siswa cenderung pasif, motivasi siswa yang kuang sehingga mereka tidak memperhatikan penjelasan guru.

Pembelajaran yang dilakukan di sekolah kurang maksimal mengakibatkan hasil belajar siswa menurun. Daftar nilai ulangan siswa kelas VII tahun pelajaran 2019/2020 semester genap dengan rata-rata nilai 30 masih jauh mencapai KKM (Kriteria Ketuntasan Minimal) yang ditetapkan Sekolah untuk mata pelajaran matematika kelas VII yaitu 60. Berdasarkan hasil wawancara dengan guru matematika SMP Negeri 8 Merauke pembelajaran menerapkan metode ceramah kemudian membuat kelompok belajar, akan tetapi kreatifitas dan partisipasi siswa belum maksimal. Penggunaan Lembar Kerja Siswa (LKS) di dalam kelas hanya berupa latihan soal yang dikerjakan lalu dikumpulkan. Lembar kerja siswa yang diterapkan guru belum disusun dengan menggunakan model pembelajaran kooperatif. LKS merupakan sumber belajar yang digunakan untuk membantu 
siswa memperbanyak informasi secara sistematis terhadap rencana yang dipelajari melalui kegiatan belajar (Rindang Wijayanto, 2017; Astuti \& Sari, 2017).

Model pembelajaran kooperatif tipe NHT membantu siswa lebih aktif dan bebas untuk mengemukakan pendapatnya kepada teman dalam kelompoknya. Selain itu, kooperatif dengan tipe NHT dapat menambah rasa percaya diri karena pada pelaksanaannya guru memberikan pertanyaan terhadap tiap kelompok dan akan dijawab sesuai dengan penomoran di tiap kelompok (Hanafi, 2017 ;Mayasari, 2019). Strategi pembelajaran yang inovatif, konstruktif, dan memotivasi keaktifan siswa serta dapat menciptakan suasana belajar yang menyenangkan dengan memfokuskan pada tercapainya kompetensi yang diharapkan dapat diwujudkan dengan LKS (Astuti \& Sari, 2017). Tujuan dari penelitian ini ialah untuk mengembangkan dan menghasilkan LKS dengan model pembelajaran kooperatif tipe NHT pada materi perbandingan yang valid dan praktis. Penelitian pengembangan adalah sebagai sesuatu pemeriksaan secara urut terhadap rancangan, pengembangan, evaluasi program, proses dan produk pembelajaran yang harus mencapai kriteria valid, praktis dan efektif ditegaskan oleh (Rindang Wijayanto, 2017).

Kooperatif dengan tipe NHT melalui Lembar Kerja Siswa dapat meningkatkan keaktifan dan kerjasama siswa dalam proses pembelajaran, sehingga diharapkan meningkatknya prestasi belajar matematika siswa di SMP Negeri 8 Merauke. Berdasarkan uraian di atas maka diperlukan suatu pengembangan LKS dengan model kooperatif tipe NHT untuk meningkatkan prestasi belajar matematika siswa kelas VIII SMP Negeri 8 Merauke.

\section{METODE PENELITIAN}

Jenis penelitian ini ialah penelitian pengembangan melalui model ADDIE (Analysis, Design, Development, Implementation, Evaluation) (Astuti \& Sari, 2017). Penelitian ini bertujuan untuk mengembangkan sebuah produk pada pelajaran matematika berupa LKS Penelitian ini dilakukan di SMP Negeri 8 Merauke dilakukan pada bulan Agustus-September 2020. Subjek penelitian ini ialah siswa kelas VIII SMP Negeri 8 Merauke tahun ajaran 2020/2021. Pengambilan sampel menggunakan pengambilan sampel acak berstrata (Stratified Random Sampling). Sampel dalam penelitian ini ialah 6 orang siswa dengan kategori prestasi belajar siswa tinggi, prestasi sedang serta prestasi rendah. Teknik pengumpulan data dengan melakukan observasi dilanjutkan dengan wawancara yang tidak tertruktur serta pemberian tes pretest dan postest dilanjutkan dengan pemberian angket.

Penilaian untuk mengukur kriteria valid perangkat pembelajaran menggunakan analisis dari hasil lembar validasi produk yang diperoleh dari ke 3 validator. Perangkat pembelajaran yang divalidasi berupa LKS. Angket validator mempunyai 5 pilihan jawaban yang memiliki aturan pembobotan sebagai berikut. 
Tabel 1. Skor Butir Penilaian Validator

\begin{tabular}{cc}
\hline Skor & Kriteria \\
\hline 5 & Sangat Valid \\
4 & Valid \\
3 & Cukup Valid \\
2 & Kurang Valid \\
1 & Tidak Valid \\
\hline
\end{tabular}

Menghitung persentase skor berdasarkan tabulasi data serta menghitung persentase skor analisis kevalidan dari LKS dan RPP menggunakan rumus sebagai berikut.

$$
\text { Persentase }=\frac{\text { Jumlah skor }}{\text { banyaknya validator }} \times 100 \%
$$

Dengan

$$
\text { persentase kelayakan }=\frac{\text { jumlah persentase }}{\text { jumlah butir pernyataan }}
$$

Analisis kepraktisan dilihat berdasarkan penilaian LKS dari angket respons siswa serta amgket respon guru serta lembar observasi keterlaksanaan pembelajaran. menghitung analisis aspek kepraktisan dengan Skala likert 1- 5 yang digunakan dalam pedoman penskoran (Sugianto, 2015).

Tabel 2.Skala Angket Guru dan Siswa

\begin{tabular}{lcc}
\hline \multirow{2}{*}{ Kategori } & \multicolumn{2}{c}{ Skor Peryataan } \\
\cline { 2 - 3 } & Positif & Negatif \\
\hline Sangat Setuju (SS) & 5 & 1 \\
Setuju (S) & 4 & 2 \\
Netral (N) & 3 & 3 \\
Tidak Setuju (TS) & 2 & 4 \\
Sangat Tidak Setuju (STS) & 1 & 5 \\
\hline
\end{tabular}

Melalui hasil lembar observasi keterlaksanaan pembelajaran adalah menggunakan tabulasi data untuk jawaban "YA" mendapat skor 1 dan 0 untuk tanggapan "TIDAK". persentasi dihitung dengan rumus berikut.

$$
k=\frac{\text { skor perolehan }}{\text { skor maksimal }} \times 100 \%
$$

Megetahui kategori peninkatan nilai pretest dan postest digunakan uji n-gain dengan gain score ternormalisasi menurut Hake (Rindang Wijayanto, 2017) yaitu: 


$$
\langle g\rangle=\frac{\left\langle S_{\text {post }}\right\rangle-\left\langle S_{\text {pre }}\right\rangle}{\text { skor maks }-\left\langle S_{\text {pre }}\right\rangle}
$$

Skor maks = skor maksimal/skor ideal (100). Adapun kriteria kualifikasi gain tertera pada Tabel 3.

Tabel 3. Kriteria Gain Ternormalisasi

\begin{tabular}{lc}
\hline Indeks Gain & Kriteria \\
\hline $\mathrm{g}>0,7$ & Tinggi \\
$0,3 \leq g \leq 0,7$ & Sedang \\
$g>0,3$ & Rendah \\
\hline
\end{tabular}

\section{HASIL DAN PEMBAHASAN}

Hasil penelitian diperoleh LKS dengan menggunakan tipe NHT dapat meningkatkan kemampuan siswa untuk bekerja sama, percaya diri dalam mengemukakan pendapat, dan terpusat kepada siswa. Sejalan dengan penelitian (Sugianto, 2015) dimana pelajaran mateatika dengan kooperatif tipe NHT menjadikan siswa lebih aktif pada kegiatan belajar.

Tahapan yang digunakan pada penelitian ini ialah dengan model pengebangan ADDIE, tetapi dalam pelaksanaannya dilakukan sampai pada tahapan hingga implementasi, untuk tahap evaluasi tidak dilaksanakan. Pada tahap awal, untuk analisis diketahui bahwa siswa masih cenderung tidak aktif dalam proses pembelajaran. Karakter dan kemampuan siswa yang tidak sama menjadikan pembelajaran kurang terlaksana dengan baik, serta belum tersedianya perangkat pembelajaran yang dapat memfasilitasi siswa agar bekerja mandiri dan membangkitkan keaktifannya.

Pada tahap kedua dilakukan tahap design, yaitu merancang perangkat pembelajaran dalam hal ini ialah LKS yang berisi masalah untuk diselesaikan siswa dengan bantuan petunjuk dari model NHT. Penelitian yang dilakukan dengan merancang Rencana Pelaksanaan Pembelajaran (RPP). Instrumen penelitian yang digunakan berupa lembar penilaian perangkat pembelajaran, soal pretest, soal posttest, angket respon guru, angket respon siswa, serta lembar observasi keterlaksanaan pembelajaran. Tahap ketiga adalah development, dimana instrumen yang diguakan memenuhi kategori valid. 
Tabel 4. Revisi LKS berdasarkan Saran validator

\begin{tabular}{|c|c|c|}
\hline \multirow{2}{*}{ Revisi } & \multicolumn{2}{|r|}{ Revisi } \\
\hline & Sebelum & Sesudah \\
\hline $\begin{array}{l}\text { Perbaikan } \\
\text { peta } \\
\text { konsep }\end{array}$ & $\begin{array}{l}\text { Peta konsep LKS berisi } \\
\text { Kompetensi Inti dan } \\
\text { Kompetensi Dasar. }\end{array}$ & $\begin{array}{l}\text { Peta konsep berisi judul bab, diikuti } \\
\text { judul sub materi, dan masing- } \\
\text { masing indikator pembelajaran. }\end{array}$ \\
\hline $\begin{array}{l}\text { Petunjuk } \\
\text { Pengerjaan }\end{array}$ & $\begin{array}{l}\text { Terdapat petunjuk umum dan } \\
\text { petunjuk kegiatan dalam LKS. }\end{array}$ & $\begin{array}{l}\text { Sesudah direvisi terdiri petunjuk } \\
\text { mengerjakan Lembar Kerja Siswa }\end{array}$ \\
\hline Tahapan & Terdapat gambar diskusi & Menghilangkan gambar diskusi \\
\hline Pengenalan & kelompok, definisi model & kelompok, serta menambahkan \\
\hline NHT & (NHT). & langkah-langkah model NHT. \\
\hline $\begin{array}{l}\text { Tampilan } \\
\text { KI,KD, } \\
\text { Indikator, } \\
\text { dan tujuan } \\
\text { pembelajar } \\
\text { an }\end{array}$ & $\begin{array}{l}\text { Berisi poin-poin dengan judul } \\
\text { dan isi di samping dari } \\
\text { kompetensi dasar, indikator, } \\
\text { dan tujuan pembelajaran. }\end{array}$ & $\begin{array}{l}\text { Ditambah dengan Kompetensi Inti } \\
\text { (KI). }\end{array}$ \\
\hline $\begin{array}{l}\text { Tampilan } \\
\text { materi ajar }\end{array}$ & $\begin{array}{l}\text { Materi digabung berdasarkan } \\
\text { sub materi. }\end{array}$ & $\begin{array}{l}\text { Materi dipisah berdasarkan } \\
\text { masing-masing tujuan } \\
\text { pembelajaran. }\end{array}$ \\
\hline $\begin{array}{l}\text { Masalah } \\
\text { pada LKS }\end{array}$ & $\begin{array}{l}\text { Pengelompokkan soal } \\
\text { berdasarkan situasi A dan B. }\end{array}$ & $\begin{array}{l}\text { Pengelompokkan soal berdasarkan } \\
\text { kasus } 1 \text { sampai kasus } 4 \text {. }\end{array}$ \\
\hline
\end{tabular}

Berdasarkan penilaian dari validator diperoleh persentase kelayakan untuk analisis kevalidan LKS sebesar 95\%. Hasilnya memperlihatkan bahwa LKS melalui model pembelajaran NHT dapat digunakan dalam pembelajaran. Tahapan yang terakhir adalah uji coba LKS. Selama proses pembelajaran siswa cenderung lebih aktif dan lebih mudah memahami setiap langkah dari panduan yang terdapat pada LKS. Guru sebagai fasilitator membantu memberi penjelasan jika siswa mengajukan pertanyaan, dalam pengerjaan masalah pada LKS, siswa cenderung mandiri dan aktif diskusi kelompok. Selanjutnya, pada sesi persentasi kelompok dengan menggunakan LKS model NHT siswa cenderung percaya diri dalam mengemukakan pendapatnya serta bertanggung jawab atas hasil kerjanya.

Tabel 5. Hasil obseravasi pembelajaran

\section{Pertemuan Ke- Persentase Kategori}

\begin{tabular}{ccc}
\hline 1 & $87 \%$ & Praktis \\
2 & $80 \%$ & Praktis \\
\hline
\end{tabular}


Data tebel 5 observasi keterlaksanaan pembelajaran diperoleh persentase untuk pertemuan I sebesar $87 \%$ memenuhi kategori praktis. Pada pertemuan II sebesar $80 \%$ sehingga memenuhi kriteria praktis. Sejalan dengan penelitian (Ellan et al., 2013) bahwa perangkat pembelajaran dengan model NHT dinilai praktis berdasarkan aktivitas guru mengelola pembelajaran dengan persentase sebesar 84,44\% untuk pertemuan 1, 93,33\% untuk pertemuan 2, dan 95,56\% untuk pertemuan ke 3. Hasil uji coba yang dilakukan secara terbatas terhadap 6 orang siswa, bahwa LKS bernilai praktis dengan persentase kelayakan sebesar 81,7\%.

Hasil penilaian LKS yang diperoleh dari angket respons guru berkisar dikategori praktis dan sangat praktis. Hasil yang diperoleh, bahwa perangkat pembelajaran yang dikembangkan ialah LKS dengan model NHT memenuhi kriteria praktis digunakan dalam pembelajaran. LKS tersebut juga dapat dikatakan sebagai media pembelajaran yang menarik membuat siswa mandiri dan bekerjasama dalam kelompok. Sejalan dengan penelitian yang dilakukan oleh Astuti (Astuti \& Sari, 2017) LKS yang digunakan kepada siswa merupakan hasil dari penelitian yang menjadi alat bantu untuk paham serta membantu siswa belajar mandiri, aktif, dan bekerja sama dengan teman sekelompoknya.

Tabel 6. Hasil tes prestasi belajar siswa

\begin{tabular}{ccccc}
\hline No & Nilai pretest & Nilai posttest & Gain Score & Keterangan \\
\hline 1 & 47 & 85 & Sedang & Tuntas \\
2 & 25 & 77 & Sedang & Tuntas \\
3 & 37 & 75 & Sedang & Tuntas \\
4 & 37 & 75 & Sedang & Tuntas \\
5 & 55 & 75 & Sedang & Tuntas \\
6 & 0 & 11 & Rendah & Tidak Tuntas \\
\hline
\end{tabular}

Peningkatan prestasi belajar enam orang siswa setelah dilakukan uji coba produk LKS dilihat dari hasil post-test. Nilai pre-test serta post-test yang dihasilkan memperlihatkan peningkatan kemampuan siswa berdasarkan uji $n$-gain. Uji $n$ gain yang diperoleh dapat disimpulkan bahwa LKS dengan model NHT yang dikembangakan oleh peneliti dari uji coba terbatas cenderung menghasilkan sisa lebih banyak prestasi yang meningkat. Sejalan dengan penelitian (Anwar et al., 2018) bahwa dengan menggunakan model pembelajaran kooperatif tipe NHT prestasi belajar matematika siswa SMP Negeri 4 Sewon, Bantul mengalami peningkatan.

Berdasarkan uraian tersebut, maka dapat disimpulkan bahwa perangkat pembelajaran yang dikembangkan berupa LKS pada materi perbandingan dengan menggunakan model pembelajaran kooperatif tipe NHT dapat meningkatkan prestasi belajar siswa. Pembelajaran dengan mode kooperatif tipe NHT yang dikembangkan memiliki kriteria valid dan praktis.

Berdasarkan rincian dan deskripsi hasil penelitian diperoleh perangkat pembelajaran berupa LKS dengan menggunakan model pembelajaran kooperatif 
tipe NHT. LKS yang dikembangkan tersebut dapat memfasilitasi siswa untuk bekerja sama, percaya diri dalam mengemukakan pendapat, dan terpusat kepada siswa. Sejalan dengan penelitian Sugianto ( 2015) bahwa penggunaan perangkat pembelajaran matematika dengan model kooperatif tipe NHT menjadikan siswa lebih aktif dalam pembelajaran. Perangkat yang dikembangkan sangat bermanfaat bagi siswa untuk membantu memahami materi pembelajaran khususnya materi perbandingan. LKS yang dikembangkan terdiri atas petunjuk penggunaan LKS dan langkah-langkah dari model NHT. proses pembelajaran LKS ini membantu siswa dalam belajar dengan mandiri, guru hanya menjelaskan secara singkat dari isi LKS tersebut. Selanjutnya siswa di dalam kelompok dapat berdiskusi untuk menyelesaikan masalah yang terdapat dalam LKS. Dalam LKS juga tersedia soal evaluasi mandiri untuk membantu melihat pemahaman siswa secara individu.

Tahapan penelitian dan pengembangan yang digunakan adalah dengan model ADDI, tetapi dalam penelitian ini hanya dilaksanakan hingga tahap implementasi, untuk tahap evaluasi tidak dilaksanakan. Pada tahap awal, untuk analysis diketahui bahwa siswa masih cenderung tidak aktif dalam proses pembelajaran. Karakter dan kemampuan siswa yang berbeda-beda menjadikan pembelajaran kurang terlaksana dengan baik, serta belum tersedianya bahan ajar yang dapat memfasilitasi siswa untuk bekerja mandiri dan membangkitkan keaktifannya. Berdasarkan analisis tersebut, maka peneliti mengembangkan media pembelajaran berupa LKS dengan menggunakan model NHT yang menarik.

Pada tahap kedua dilakukan tahap design, yaitu merancang perangkat pembelajaran berupa LKS yang berisi masalah untuk diselesaikan siswa dengan bantuan petunjuk dari model NHT. Pada tahap ini peneliti merancang Rencana Pelaksanaan Pembelajaran (RPP), instrumen penelitian yang terdiri dari lembar penilaian perangkat pembelajaran, soal pre-test, soal post-test, angket respon guru, angket respons siswa, dan lembar observasi keterlaksanaan pembelajaran. Tahap ketiga adalah pengembangan, pada tahap ini perangkat pembelajaran LKS yang telah dikembangkan dilakukan validasi sebanyak dua kali dengan validator. Saran dan masukan dari validator menjadi bahan perbaikan perangkat pembelajaran, yang kemudian dilakukan revisi hingga LKS bernilai valid. Berdasarkan penilaian dari validator diperoleh persentase kelayakan untuk analisis kevalidan LKS sebesar 95\%. Hasil tersebut menunjukkan bahwa LKS dengan model pembelajaran NHT dapat digunakan dalam pembelajaran.

Tahap terakhir adalah implementation atau uji coba LKS. Pada tahap ini siswa menggunakan LKS dalam pembelajaran. Selama proses pembelajaran siswa cenderung lebih aktif dan lebih mudah memahami setiap langkah dari panduan yang terdapat pada LKS. Guru sebagai fasilitator membantu memberi penjelasan jika siswa mengajukan pertanyaan, dalam pengerjaan masalah pada LKS, siswa cenderung mandiri dan aktif diskusi kelompok. Selanjutnya, pada sesi persentasi kelompok dengan menggunakan LKS model NHT siswa cenderung percaya diri dalam mengemukakan pendapatnya serta bertanggung jawab atas hasil kerjanya. Dalam proses pembelajaran guru mengamati dan mengisi angket observasi keterlaksanaan pembelajaran.

Setelah ujicoba dilaksanakan siswa dan guru mengisi angket penilaian dari LKS tersebut. Data hasil perhitungan nilai lembar observasi keterlaksanaan pembelajaran diperoleh persentase untuk pertemuan pertama sebesar $87 \%$ dan 
pertemuan kedua sebesar $80 \%$ sehingga memenuhi kriteria praktis. Sejalan dengan penelitian (Ellan et al., 2013) bahwa perangkat pembelajaran dengan model NHT dinilai praktis berdasarkan aktivitas guru mengelola pembelajaran dengan persentase sebesar $84,44 \%$ untuk pertemuan 1, 93,33\% untuk pertemuan 2 , dan 95,56\% untuk pertemuan ke 3 . Hasil uji coba yang dilakukan secara terbatas terhadap 6 orang siswa, bahwa LKS bernilai praktis dengan persentase kelayakan sebesar 81,7\%. Hasil penilaian LKS yang diperoleh dari angket respons guru hanya berkisar di kategori praktis dan sangat praktis saja.

Hasil yang diperoleh, menunjukkan bahwa perangkat pembelajaran yang dikembangkan berupa LKS dengan model NHT memenuhi kriteria praktis digunakan dalam pembelajaran. LKS tersebut juga dapat dikatakan sebagai media pembelajaran yang menarik membuat siswa mandiri dan bekerjasama dalam kelompok. Sejalan dengan penelitian yang dilakukan oleh Astuti (Astuti \& Sari, 2017) LKS yang dihasilkan dapat digunakan oleh siswa sebagai alat bantu untuk memahami materi serta membantu siswa belajar mandiri, aktif, dan bekerja sama dengan teman sekelompoknya.

Peningkatan prestasi belajar enam orang siswa setelah dilakukan uji coba produk LKS dilihat dari hasil post-test. Hasil yang diperoleh dari nilai pre-test dan post-test bahwa mengalami peningkatan berdasarkan uji $n$-gain. Uji $n$-gain yang diperoleh dapat disimpulkan bahwa LKS dengan model NHT yang dikembangakan oleh peneliti dari uji coba terbatas lebih banyak siswa yang mengalami peningkatan prestasi. Sejalan dengan penelitian Anwar(Anwar et al., 2018) bahwa dengan menggunakan model pembelajaran kooperatif tipe NHT prestasi belajar matematika siswa SMP Negeri 4 Sewon, Bantul mengalami peningkatan.

Berdasarkan uraian tersebut, maka LKS dengan materi perbandingan yang menggunakan model pembelajaran kooperatif tipe NHT dapat membantu siswa lebih aktif, mandiri, mampu bekerja sama dalam kelompok, percaya diri dalam mengemukakan pendapat, dan terpusat pada siswa serta dapat meningkatkan prestasi belajar siswaLKS dengan model pembelajaran kooperatif tipe NHT memiliki kualitas valid dan praktis.

\section{KESIMPULAN DAN SARAN}

Pengembangan produk LKS melalui tipe NHT dengan mode koopeatif yang dilakukan validasi sebanyak dua kali oleh 3 validator hingga LKS dinyatakan valid. Penilaian dari angket respons siswa, respons guru dan observasi keterlaksaaan pembelajaran bahwa LKS dinyatakan praktis digunakan dalam pembelajaran. Dengan demikian, dapat disimpulkan bahwa LKS dengan tipe NHT melalui model kooperatif pada materi perbandingan untuk kelas VII dinyatakan valid dan praktis. Hasil pengembangan LKS bahwa penilaian dari ketiga validator LKS memperoleh persentase nilai sebesar 95\% dengan kriteria valid. Hasil penilaian kepraktisan dari angket respons siswa untuk uji coba terbatas sebesar 81,7\% dengan kreteria praktis. Hasil angket respons guru memiliki kriteria praktis dengan persentase skor sebesar 68,75\% dan kategori sangat praktis sebesar $31,25 \%$. Sedangkan untuk hasil penilaian angket observasi pembelajaran untuk pertemuan pertama didapat skor persentase sebesar $87 \%$ untuk pertemuan dua dengan persentase sebesar $80 \%$ sehingga memenuhi kriteria praktis. Hasil uji $N$ - 
gain bahwa LKS dengan mengaplikasikan tipe NHT pada model kooperatif dapat meningkatkan prestasi belajar siswa.

\section{DAFTAR PUSTAKA}

Anwar, K., Ari, T., Sri, S., Widodo, A., \& Pendahuluan, A. (2018). Pengaruh Model Pembelajaran Kooperatif Tipe Numbered Heads Together (NHT) Terhadap Prestasi Belajar Matematika Siswa. Prosiding Seminar Nasional Etnomatnesia, (6), 790-794.

Astuti, A., \& Sari, N. (2017). Pengembangan Lembar Kerja Siswa (LKS) Pada Mata Pelajaran Matematika Siswa Kelas X Sma. Jurnal Cendekia : Jurnal Pendidikan Matematika, 1(2), 13-24.

Ellan, Hobri, \& Nurcholif. (2013). Pengembangan Perangkat Pembelajaran Matemaika Benuansa Karakter Dengan Pembelajaran Kooperatif numbered Head Together (NHT) Pokok Bahasan Operasi Bentuk Aljabar Kelas VII SMP Neger 1 Pakusari. Науковий Вісник Львівського Національного Університету Ветеринарної Медицини Та Біотехнологій Імені С.з. Гжицького, 15(3-2), 1-12.

Fitriani, E., \& Aksa, S. (2014). Perbandingan Model Pembelajaran Kooperaif Numbered Head Together (NHT) Dengan Konvensional Terhadap Hasil Belajar Siswa Pada Materi Ketenagakerjaan. Jurnal Sains Ekonomi dan Edukasi, II(2), 1-9.

Hanafi. (2017). Konsep Penelitian R \& D Dalam Bidang Pendidikan. Saintifika Islamica: Jurnal Kajian Keislaman, 4(2), 129-150.

Mayasari, D. (2019). Pengembangan Bahan Ajar Segitiga Dengan Pendekatan Open Ended Untuk Meningkatkan Kemampuan Pemecahan Masalah Matematika. Jurnal Inomatika, 1(2), 99-109.

Natsir, I., Munfarikhatin, A., \& Taufik, A. R. (2020). Development of Student Worksheeet Based on Blended Learning Oriented to Multiple Intelligences in Algebra, 473(Icss), 438-442.

Pagiling, S., Palobo, M., Munfarikhatin, A., Mayasari, D., \& Taufik, A. (2019). Exploration of College Student's Representations in Solve The Problem of Numeric Methods, 383(Icss), 134-136.

Panjaitan, L., Palenewen, E., \& Maasawet, E. T. (2017). Pengembangan Lembar Kerja Siswa (LKS) Melalui Model Numbered Heads Together (NHT) Pada Mata Pelajaran IPA Biologi Kelas VII SMP Negeri 3 Samarinda Tahun Ajaran 2016 / 2017. Prosiding Seminar Nasional II Biologi Sains dan Pembelajaran, 310-324.

Sugianto, L. (2015). Pengembangan perangkat pembelajaran pada materi differensial dengan model kooperatif tipe number head together (NHT). Seminar Nasional, 03, 450-470.

Taufik, A., Pagiling, S., Mayasari, D., Munfarikhatin, A., Natsir, I., \& Dadi, O. (2019). The Metacognition of Junior High School Students in Posing Mathematical Problems Viewed From Cognitive Style, 383(1), 137-143.

Wijayanto, R., \& Santoso, R. H. (2017). Pengembangan Bahan Ajar Matematika Dengan Pendekatan Problem Solving Berorientasi Pada Kemampuan Pemecahan Masalah. Journal of Education, 1(1), 4. 